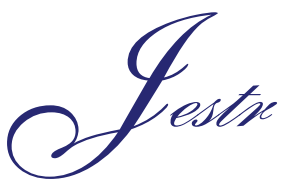

\title{
Development of mathematical model to predict the mechanical properties of friction stir welded AA6351 aluminum alloy
}

\author{
R. Palanivel ${ }^{*}, 1$, P. Koshy Mathews ${ }^{2}$ and N. Murugan ${ }^{3}$ \\ ${ }^{1}$ Faculty in Department of Mechanical Engineering, Kalaivani College of Technology, Coimbatore, Tamilnadu 641105, India. \\ ${ }^{2}$ Principal, Kalaivani College of Technology, Coimbatore, Tamilnadu 641105, India. \\ ${ }^{3}$ Professor, Welding Research Cell, Department of Mechanical Engineering, Coimbatore Institute of Technology, \\ Coimbatore, Tamilnadu 641014 India.
}

Received 17 June 2010; Revised 13 July 2010, Accepted 20 October 2010

\begin{abstract}
This paper presents a systematic approach to develop the mathematical model for predicting the ultimate tensile strength, yield strength, and percentage of elongation of AA6351 aluminum alloy which is widely used in automotive, aircraft and defense Industries by incorporating (FSW) friction stir welding process parameter such as tool rotational speed, welding speed, and axial force. FSW has been carried out based on three factors five level central composite rotatable design with full replications technique. Response surface methodology (RSM) is employed to develop the mathematical model. Analysis of variance (ANOVA) Technique is used to check the adequacy of the developed mathematical model. The developed mathematical model can be used effectively at $95 \%$ confidence level. The effect of FSW process parameter on mechanical properties of AA6351 aluminum alloy has been analyzed in detail.
\end{abstract}

Keywords: Friction stir welding; Design Expert; Design Of Experiments; ANOVA; RSM.

\section{Introduction}

Friction stir welding is a solid state welding process, in which a rotating tool moves along the joint interface, generating heat and resulting in a re-circulating flow of plasticized material near the tool surface [1-4]. This plasticized material is subjected to extrusion by the tool pin rotational and traverse movements leading to the formation of the so-called stir zone. The formation of the stir zone is affected by the material flow behavior under the action of the rotating tool.

The FSW process is applied presently for welding aluminum and magnesium alloys as well as copper, steel, composites and dissimilar materials [5-9]. Welding of aluminum alloy especially heat treatable wrought aluminum alloy of AA6XXX aluminum by FSW [10] produces better quality than other fusion welding process like gas metal arc welding $[11,12]$. In this study, deformable aluminum alloy AA6351 is chosen which is used in shipbuilding due to the high strength, resistance to seawater corrosion, and good processibility and weldability [13]. Elongovan et al. [14] reported the effect of FSW process parameters on mechanical properties of FS welded AA6061 aluminum alloy. They found that the tensile strength initially increased with the increase in tool rotational speed, welding speed and axial force but the tensile strength decreased after reaching a maximum value with the further increase of the these parameters. The response surface methodology (RSM) [15-18] was used to analyze the effects of process parameters. As the effects of FSW process parameters on the mechanical properties of aluminum alloy AA6351 is not analyzed, hence an attempt has been made to develop a mathematical model to predict the mechanical properties such as ultimate tensile strength, yield strength, and percentage of elongation of friction stir welded AA6351 aluminum alloy for any given FSW process parameter $\mathrm{S}$ and to analyze the effects of FSW process parameters on the tensile strength, yield strength, and percentage of elongation. The developed models are tested for their adequacy and accuracy using ANOVA and confirmation tests, respectively.

\section{Experimental work}

The test plates of size $100 \mathrm{~mm}$ X $50 \mathrm{~mm}$ X $6 \mathrm{~mm}$ are prepared from aluminum alloy AA6351 rolled plates using CNC cutting machine. The chemical composition and mechanical properties of the base material are presented in Table 1 and Table 2, respectively. The experiment is conducted using FSW machine developed by of R.V.S Machine Tool, Coimbatore as shown in Figure 1 to fabricate the joints. The welding was done by single pass. 
Table 1. Chemical composition of AA6351 alloy.

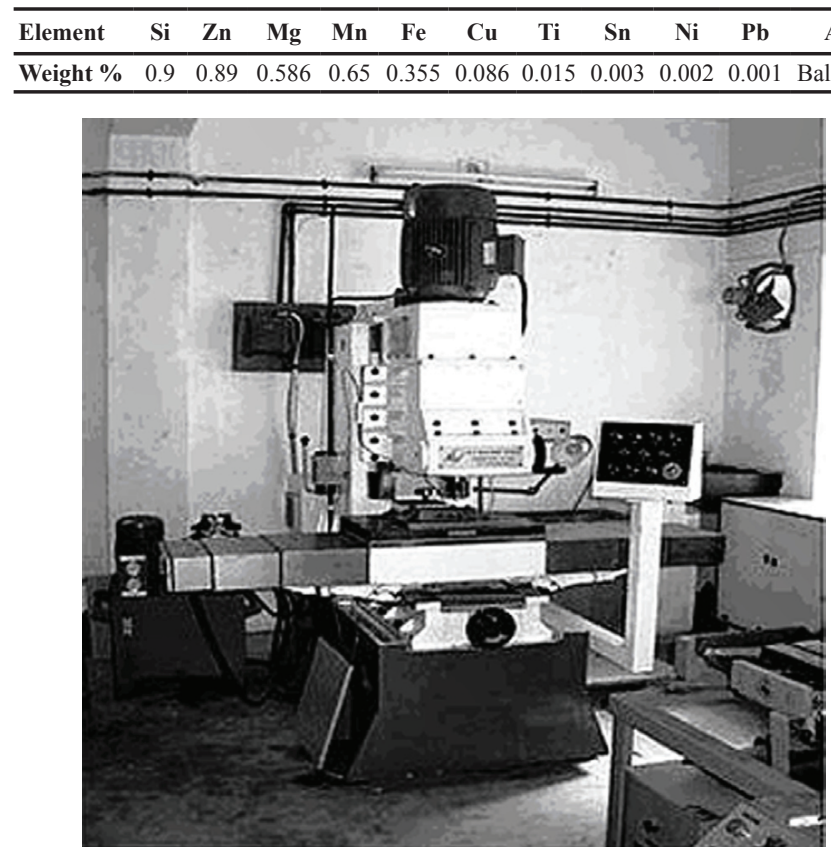

Figure 1. Friction stir welding machine

Table 2. Mechanical properties of AA6351 alloy.

\begin{tabular}{cccc}
\hline $\begin{array}{c}\text { Base } \\
\text { Material }\end{array}$ & $\begin{array}{c}\text { Tensile Strength } \\
\text { (MPa) }\end{array}$ & $\begin{array}{c}\text { Yield Strength } \\
\text { (MPa) }\end{array}$ & $\begin{array}{c}\text { Percentage of } \\
\text { elongation }\end{array}$ \\
\hline AA6351 & 310 & 285 & 14 \\
\hline
\end{tabular}

Out of various tool materials like tool steel, high speed steel, high carbon high chromium steel $(\mathrm{HCHCr})$, carbide, and carbon boron nitride, $\mathrm{HCHCr}$ steel is chosen as tool material because of its high strength, high hot hardness, easy to process, easily available and low cost [19]. The FSW tools are manufactured using CNC Turning center and wire cut EDM (WEDM) machine.

The configuration of the designed FSW Tool is:

- Tool pin profile of square without draft

- Tools having ratio of shoulder diameter to pin diameter $(\mathrm{D} / \mathrm{d})$ is 3 has been chosen for this study because it is having good joining properties among various pin configurations [20]. The manufactured tool is shown in Figure 2.

\section{Plan of investigation}

The research work was planned to be carried out in the following steps:

1. Identifying the important process parameter

2. Finding the upper and lower limits of the process parameter Viz. tool rotational speed $(\mathrm{N})$, welding speed $(\mathrm{S})$, and axial force $(\mathrm{F})$

3. Development of design matrix

4. Conducting the experiments as per the design matrix

5. Recording the responses, viz. Ultimate Tensile Strength (UTS),

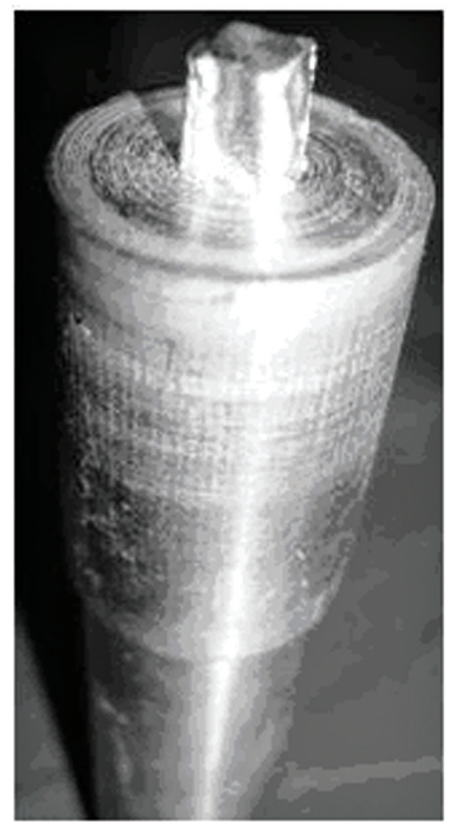

Figure 2. The manufactured square pin profile tool

Yield Strength (YS), Percentage of Elongation (POE)

6. Development of the mathematical model

7. Checking the adequacy of the models developed

8. Conducting the conformity test runs and comparing the results.

9. Presenting the effects of the process parameters on the mechanical properties in graphical form and analyzing the results.

\subsection{Identifying the important process parameter:}

Based on preliminary trials, the independent process parameters affecting the mechanical properties were identified as: tool rotational speed $(\mathrm{N})$, welding speed $(\mathrm{S})$ and axial force $(\mathrm{F})$.

\subsection{Finding the limits of control variable}

Trial runs are conducted to find the upper and lower limit of process parameters, by varying one of the parameter and keeping the rest of them at constant values. Feasible limits of the parameters were chosen in such a way that the joint should be free from visible defects shown in Figure 3. The upper limit of a factor was coded as +1.682 and lower limit as -1.682 . The intermediate coded values being calculated from the following relationship.

$\mathrm{X}_{\mathrm{i}}=1.682\left[2 \mathrm{X}-\left(\mathrm{X}_{\max }+\mathrm{X}_{\min }\right)\right] /\left(\mathrm{X}_{\max }-\mathrm{X}_{\min }\right)$

Where $X_{i}$ is the required coded value of a variable $X$; and $X$ is any value of the variable from $X_{\min }$ to $X_{\max }, X_{\min }$ is the lower limit of the variable and $\mathrm{X}_{\max }$ is the upper limit of the variable [18]. The selected process parameters with their limits, units and notations are given in Table 3 . 
Table 3. Process parameter and its levels.

\begin{tabular}{lccccccc}
\hline \multirow{2}{*}{ Parameters } & \multirow{2}{*}{ Units } & \multirow{2}{*}{ Notations } & \multicolumn{6}{c}{ Levels } \\
\cline { 4 - 8 } $\begin{array}{l}\text { Rotational } \\
\text { speed }\end{array}$ & $\mathrm{rpm}$ & $\mathrm{N}$ & 600 & 782 & 1050 & 1317 & 1500 \\
$\begin{array}{l}\text { Welding } \\
\text { speed }\end{array}$ & $\mathrm{mm} / \mathrm{s}$ & $\mathrm{S}$ & 0.45 & 0.85 & 1.42 & 2 & 2.4 \\
$\begin{array}{l}\text { Axial force } \\
\text { tones }\end{array}$ & $\mathrm{F}$ & 1 & 1.2 & 1.5 & 1.8 & 2 \\
\hline
\end{tabular}

\subsection{Development of Design Matrix}

The selected design matrix is shown in Table 4. It is a three factor five level central composite rotatable designs consisting of 20 sets of coded conditions composed of a full factorial $2^{3}=8$, plus 6 centre points and 6 star points thus 20 experimental runs allowed the estimation of the linear, quadratic and two way interactive effects of the process parameter on the mechanical properties.

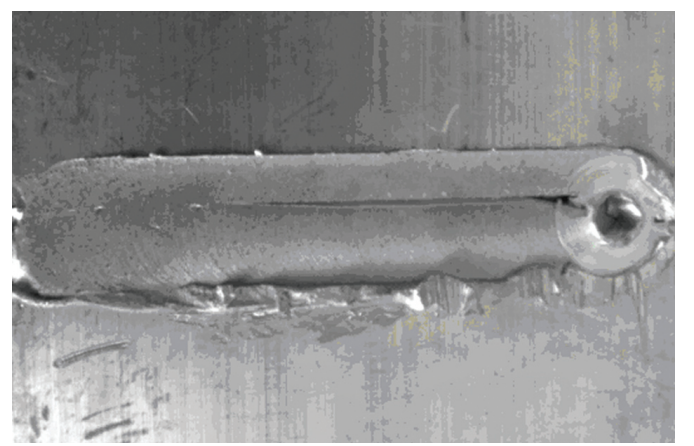

Figure 3. Typical FS welded plate having tunneling defect in welded area

\subsection{Conducting the experiment as per the design matrix}

The experiments were conducted as per the design matrix at random, to avoid the possibility of systematic errors infiltrating in to the system.

\subsection{Recording of the responses}

Tensile test specimens are prepared as per ASTM E8 standard shown in Figure 4 and transverse tensile properties such as ultimate tensile strength, yield strength, and percentage of elongation of the FS welded joints are evaluated using computerized UTM. For each welded plate, three specimens are prepared and tested. Figure 5 shows tensile specimen after fracture for three set of welds. The average values of the results obtained from those specimens are tabulated and presented in Table 4.
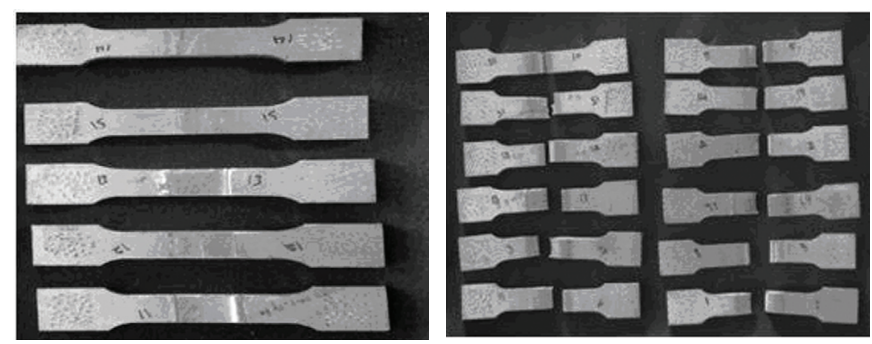

Figure 4. Typical tensile specimens

Figure 5. Tensile specimen after fracture
Table 4. Design matrix and estimated mechanical properties.

\begin{tabular}{|c|c|c|c|c|c|c|}
\hline \multirow[t]{2}{*}{$\begin{array}{l}\text { Trail } \\
\text { No }\end{array}$} & \multicolumn{3}{|c|}{$\begin{array}{c}\text { Design matrix } \\
\text { FSW Process } \\
\text { parameters }\end{array}$} & \multicolumn{3}{|c|}{$\begin{array}{c}\text { Estimated mechanical } \\
\text { properties }\end{array}$} \\
\hline & $\begin{array}{c}\mathrm{N} \\
(\mathbf{r p m})\end{array}$ & $\underset{(\mathbf{m m} / \mathbf{s})}{\mathrm{S}}$ & $\begin{array}{c}\mathrm{F} \\
\text { (tones) }\end{array}$ & $\begin{array}{l}\text { Ultimate } \\
\text { tensile } \\
\text { strength } \\
\text { (MPa) }\end{array}$ & $\begin{array}{c}\text { Yield } \\
\text { strength } \\
\text { (MPa) }\end{array}$ & $\begin{array}{l}\text { Percent- } \\
\text { age of } \\
\text { elogana- } \\
\text { tion }\end{array}$ \\
\hline 1 & -1 & -1 & -1 & 219 & 193 & 5.24 \\
\hline 2 & 1 & -1 & -1 & 203 & 177 & 4.31 \\
\hline 3 & -1 & 1 & -1 & 220 & 194 & 5.3 \\
\hline 4 & 1 & 1 & -1 & 182 & 156 & 2.58 \\
\hline 5 & -1 & -1 & 1 & 192 & 165 & 3.61 \\
\hline 6 & 1 & -1 & 1 & 219 & 192 & 5.23 \\
\hline 7 & -1 & 1 & 1 & 195 & 168 & 3.72 \\
\hline 8 & 1 & 1 & 1 & 197 & 171 & 3.78 \\
\hline 9 & -1.682 & 0 & 0 & 217 & 190 & 5.12 \\
\hline 10 & 1.682 & 0 & 0 & 199 & 172 & 3.82 \\
\hline 11 & 0 & -1.682 & 0 & 193 & 166 & 3.61 \\
\hline 12 & 0 & 1.682 & 0 & 202 & 175 & 4.28 \\
\hline 13 & 0 & 0 & -1.682 & 201 & 174 & 4.23 \\
\hline 14 & 0 & 0 & 1.682 & 220 & 192 & 5.31 \\
\hline 15 & 0 & 0 & 0 & 219 & 189 & 5.24 \\
\hline 16 & 0 & 0 & 0 & 217 & 187 & 5.13 \\
\hline 17 & 0 & 0 & 0 & 216 & 186 & 5.09 \\
\hline 18 & 0 & 0 & 0 & 218 & 188 & 5.1 \\
\hline 19 & 0 & 0 & 0 & 215 & 184 & 5 \\
\hline 20 & 0 & 0 & 0 & 214 & 183 & 4.88 \\
\hline
\end{tabular}

\subsection{Development of mathematical model}

Ultimate tensile strength, yield strength, and percentage of elongation of the joints are functions of rotational speed, welding speed, and axial force and it can be expressed as

$$
\mathrm{Y}=\mathrm{f}(\mathrm{N}, \mathrm{S}, \mathrm{F})
$$

Where

Y-The response

N- Rotational speed, rpm

S- Welding Speed, $\mathrm{mm} / \mathrm{s}$

F - Axial Force, tones.

For the three factors, the selected polynomial (regression) could be expressed as

$$
\begin{aligned}
\mathrm{Y}= & \mathrm{b}_{0}+\mathrm{b}_{1} \mathrm{~N}+\mathrm{b}_{2} \mathrm{~S}+\mathrm{b}_{3} \mathrm{~F}+\mathrm{b}_{11} \mathrm{~N}^{2}+\mathrm{b}_{22} \mathrm{~S}^{2}+\mathrm{b}_{33} \mathrm{~F}^{2}+ \\
& +\mathrm{b}_{12} \mathrm{NS}+\mathrm{b}_{13} \mathrm{NF}+\mathrm{b}_{23} \mathrm{~S}
\end{aligned}
$$

Where $b_{0}$ is the free term of the regression equation, the coefficients b1, b2, and b3 are linear terms, the coefficients b11, b22, 
and b33, are quadratic terms, and the coefficients, b12, b13, and b23, are interaction terms. The values of the coefficients are calculated by regression analysis with the help of following equations [21]:

$$
\begin{aligned}
& \mathrm{b}_{\mathrm{o}}=0.1663 \sum(\mathrm{Y})-0.0568 \sum \sum\left(\mathrm{X}_{\mathrm{ii}} \mathrm{Y}\right) \\
& \mathrm{b}_{\mathrm{j}}=0.0732\left(\mathrm{X}_{\mathrm{i}} \mathrm{Y}\right) \\
& \mathrm{b}_{\mathrm{ii}}=0.0625 \sum\left(\mathrm{X}_{\mathrm{ii}} \mathrm{Y}\right)+0.00689 \sum \sum\left(\mathrm{X}_{\mathrm{ii}} \mathrm{Y}\right)-0.0568 \sum(\mathrm{Y}) \\
& \mathrm{b}_{\mathrm{ij}}=0.1250 \sum\left(\mathrm{X}_{\mathrm{ij}} \mathrm{Y}\right)
\end{aligned}
$$

DESIGN EXPERT 7.1.6 software packages are used to calculate the values of those coefficients for different responses and are presented in Table 5. After determining the coefficients, the mathematical models are developed.

\subsection{Developed final mathematical model}

The developed final mathematical model equations in the coded form are given below:

Table 5. Estimated regression coefficients of mathematical models.

\section{Model}

\begin{tabular}{cccc}
\hline $\begin{array}{c}\text { Regression } \\
\text { coefficients }\end{array}$ & $\begin{array}{c}\text { Ultimate Tensile } \\
\text { Strength, MPa }\end{array}$ & $\begin{array}{c}\text { Yield Strength, } \\
\text { MPa }\end{array}$ & $\begin{array}{c}\text { Percentage of } \\
\text { Eloganation }\end{array}$ \\
\hline $\mathrm{b}_{0}$ & 216.54 & 186.19 & 5.08 \\
$\mathrm{~b}_{1}$ & -4.05 & -3.97 & -0.30 \\
$\mathrm{~b}_{2}$ & -1.75 & -1.67 & -0.14 \\
$\mathrm{~b}_{3}$ & 0.80 & 0.46 & 0.05 \\
$\mathrm{~b}_{12}$ & -5.87 & -5.75 & 0.42 \\
$\mathrm{~b}_{13}$ & 10.38 & 10.50 & 0.67 \\
$\mathrm{~b}_{23}$ & 0.13 & 0.25 & 0.04 \\
$\mathrm{~b}_{11}$ & -3.28 & -1.97 & -0.24 \\
$\mathrm{~b}_{22}$ & -6.99 & -5.68 & -0.43 \\
$\mathrm{~b}_{23}$ & -2.39 & -1.26 & -0.14 \\
\hline
\end{tabular}

Ultimate tensile strength,

$\mathbf{M P a}=216.54-4.05 \mathrm{~N}-1.75 \mathrm{~S}+0.80 \mathrm{~F}-5.87 \mathrm{NS}+10.38 \mathrm{NF}$ $+0.13 \mathrm{SF}-3.21 \mathrm{~N}^{2}-6.99 \mathrm{~S}^{2}-2.39 \mathrm{~F}^{2}$

Yield strength,

$\mathbf{M P a}=186.19-3.97 \mathrm{~N}-1.67 \mathrm{~S}+0.46 \mathrm{~F}-5.75 \mathrm{NS}+10.50 \mathrm{NF}$ $+0.25 \mathrm{SF}-1.97 \mathrm{~N}^{2}-5.68 \mathrm{~S}^{2}-1.26 \mathrm{~F}^{2}$

Percentage of elongation $=5.08-0.30 \mathrm{~N}-0.14 \mathrm{~S}+0.05 \mathrm{~F}$ $+0.42 \mathrm{NF}+0.04 \mathrm{SF}-0.24 \mathrm{~N}^{2}-0.43 \mathrm{~S}^{2}-0.14 \mathrm{~F}^{2}$

\subsection{Checking the adequacy of the developed model}

The adequacy of the models so developed is then tested by using the analysis of variance technique (ANOVA). Using this technique, it is found that calculated $\mathrm{F}$ ratios are larger than the tabulated values at a 95\% confidence level; hence, the models are considered to be adequate [22]. Another criterion that is commonly used to illustrate the adequacy of a fitted regression model is the coefficient of determination $\left(\mathrm{R}^{2}\right)$. For the models developed, the calculated $R^{2}$ values and adjusted $R^{2}$ values are above $80 \%$ and $70 \%$, respectively. These values indicate that the regression models are quite adequate. The results of the ANOVA are given in Table 6.The validity of regression models developed is further tested by drawing scatter diagrams. Typical scatter diagrams for all the models are presented in Figure 6-8. The observed values and predicted values of the responses are scattered close to the $45^{\circ}$ line, indicating an almost perfect fit of the developed empirical models [23].

\begin{tabular}{|c|c|c|c|c|c|c|c|c|c|c|}
\hline & \multicolumn{2}{|c|}{ Sum of squares } & \multicolumn{2}{|c|}{ Mean squares } & \multicolumn{2}{|c|}{ Degrees of freedom } & \multirow[t]{2}{*}{ F- Ratio } & \multirow[t]{2}{*}{$\begin{array}{c}\mathbf{R}^{2} \\
\text { value }\end{array}$} & \multirow[t]{2}{*}{$\begin{array}{c}\text { Adjusted } \\
\mathbf{R}^{2} \text { value }\end{array}$} & \multirow[t]{2}{*}{ Remarks } \\
\hline & Regression & Residual & Regression & Residual & Regression & Residual & & & & \\
\hline UTS & 2243.74 & 456.06 & 249.3 & 45.61 & 9 & 10 & 5.47 & 0.83 & 0.80 & Adequate \\
\hline YS & 1902.82 & 460.97 & 211.42 & 46.09 & 9 & 10 & 4.58 & 0.80 & 0.77 & Adequate \\
\hline $\begin{array}{l}\text { Percentage of } \\
\text { Elongation }\end{array}$ & 9.81 & 1.99 & 1.09 & 0.19 & 9 & 10 & 5.47 & 0.83 & 0.81 & Adequate \\
\hline
\end{tabular}

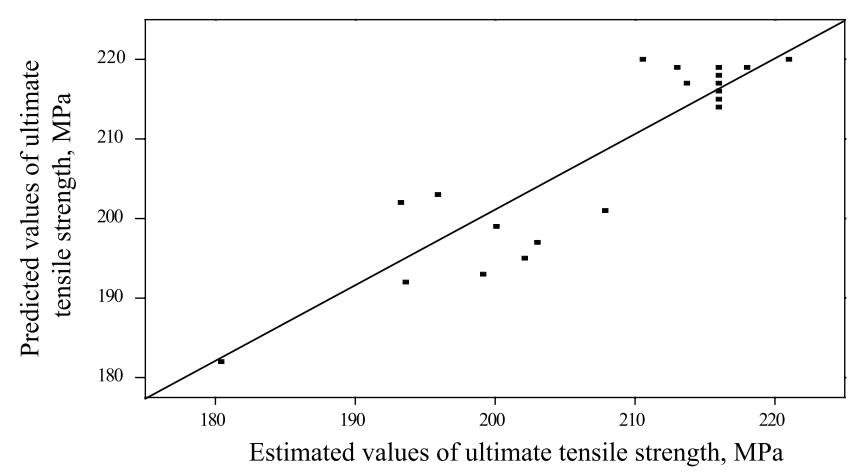

Figure 6. Scatter diagram of the ultimate tensile strength

Table 6. ANOVA test results.

UTS $=$ Ultimate tensile strength, YS = Yield Strength, From F Table, F $(9,10,0.05)=3.02$ 


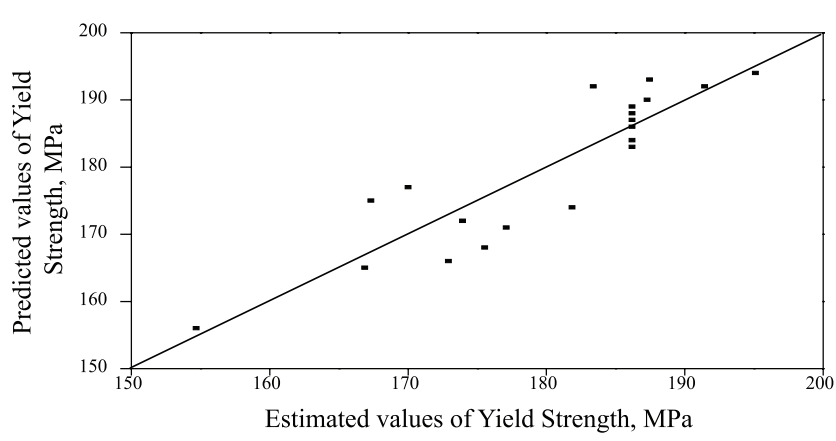

Figure 7. Scatter diagram of the yield strength

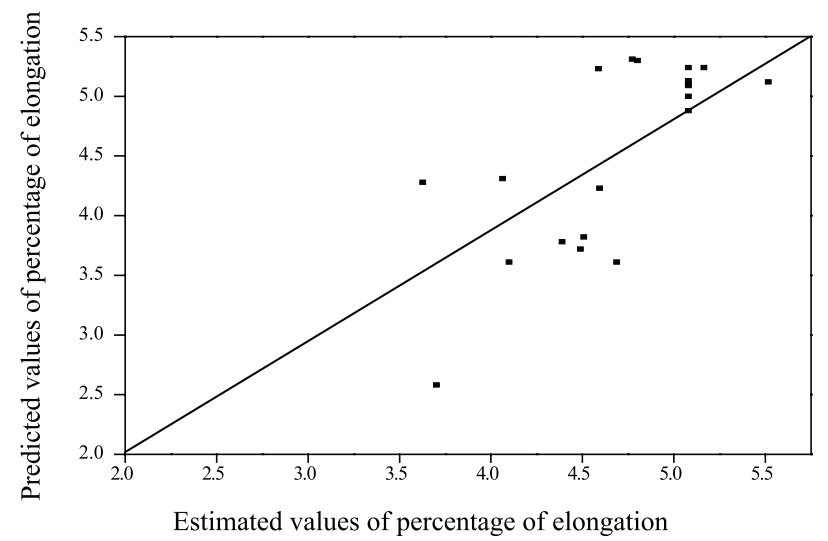

Figure 8. Scatter diagram of the percentage of elongation

\subsection{Confirmation experiments}

Experiments are conducted to verify the regression equations ((7) - (9)). Five weld runs are made using different values of rotational speed, welding speed and axial force other than what were used in the design matrix. The results obtained are quite satisfactory and the details are presented in Table 7.

\section{Analysis of the results}

The effects of the different process parameter on the mechanical properties of FS welded aluminum alloy AA6351 are predicted from the mathematical models using the experimental observations are presented in Figures (9-11) showing the general trends between cause and effect.

\subsection{Effect of rotational speed $(\mathrm{N})$}

Figure 9 shows the direct effect of rotational speed on mechanical properties. It is seen that as the rotational speed increases the tensile strength, yield strength and percentage of elongation of FS welded aluminum alloy AA6351 increases and then it decreases. The highest rotational speed results in the metallurgical transformation such as solubilisation, re- precipitation, and coarsening of strengthening precipitates at the weld zone and lowering of dislocation density which decrease the tensile strength of the FS welded joints [24]. It is clear that in FSW as the rotational speed increases the heat input also increases. More heat input destroys the regular flow behavior. These results almost agree with Elongovan et al. [14].

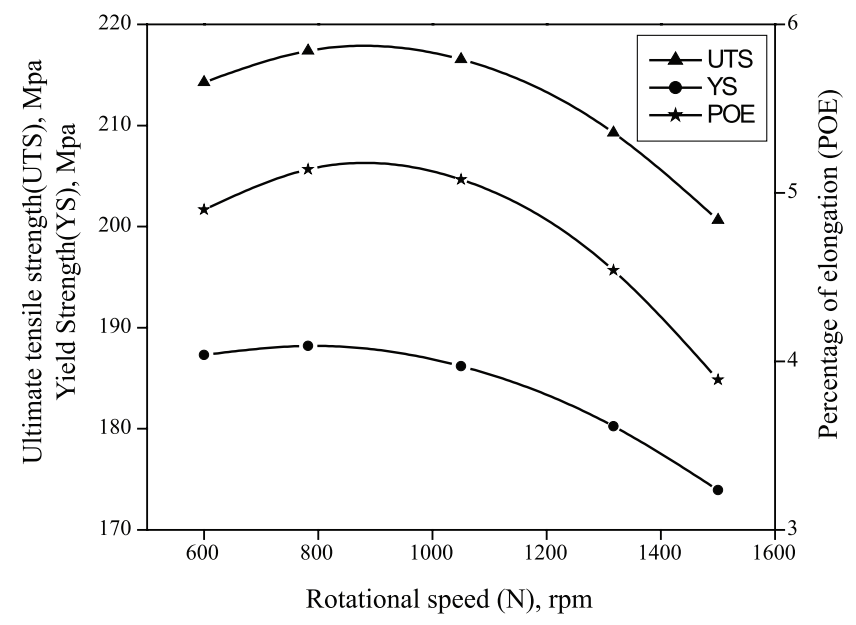

Figure 9. Direct effect of rotational speed on mechanical properties

Table 7. Results of confirmation experiment.

\begin{tabular}{|c|c|c|c|c|c|c|c|c|c|c|c|}
\hline \multicolumn{3}{|c|}{ FSW Parameters } & \multicolumn{2}{|c|}{ Ultimate tensile strength, $\mathrm{MPa}$} & \multirow{2}{*}{$\begin{array}{c}\text { Error } \\
(\%)\end{array}$} & \multicolumn{2}{|c|}{ Yield strength, $\mathrm{MPa}$} & \multirow{2}{*}{$\begin{array}{c}\text { Error } \\
(\%)\end{array}$} & \multicolumn{2}{|c|}{ Percentage of elongation } & \multirow[b]{2}{*}{$\begin{array}{c}\text { Error } \\
(\%)\end{array}$} \\
\hline $\mathrm{N}$ & S & $\mathrm{F}$ & $\begin{array}{c}\text { Estimated, } \\
\mathrm{MPa}\end{array}$ & $\begin{array}{c}\text { Predicted, } \\
\mathrm{MPa}\end{array}$ & & $\begin{array}{c}\text { Estimated, } \\
\mathrm{MPa}\end{array}$ & $\begin{array}{l}\text { Predicted, } \\
\quad \mathrm{MPa}\end{array}$ & & $\begin{array}{c}\text { Estimated, } \\
\mathrm{MPa}\end{array}$ & $\begin{array}{l}\text { Predicted, } \\
\mathrm{MPa}\end{array}$ & \\
\hline 1050 & 1.42 & 1.45 & 219 & 216.54 & 2.46 & 189 & 186.00 & 1.61 & 5.24 & 5.08 & 3.14 \\
\hline 600 & 1.42 & 1.45 & 217 & 214.00 & 3.00 & 190 & 187.29 & 1.44 & 5.12 & 4.89 & 4.70 \\
\hline 1500 & 1.42 & 1.5 & 199 & 200.44 & -1.44 & 172 & 173.93 & -1.10 & 3.82 & 4.05 & 5.60 \\
\hline 1050 & 0.42 & 1.5 & 193 & 199.70 & -6.70 & 166 & 172.92 & -4.00 & 3.61 & 3.52 & 2.55 \\
\hline 1050 & 1.42 & 1.0 & 202 & 208.43 & -6.43 & 175 & 181.85 & -3.76 & 4.28 & 4.59 & -6.75 \\
\hline
\end{tabular}

Percentage of error $=\frac{\text { Estimated values }- \text { predicted value }}{\text { Predicted values }} \times 100$ 


\subsection{Effect of welding speed (S)}

Figure 10 shows the direct effect of welding speed on mechanical properties. It is evident that as welding speed increases from 0.5 $\mathrm{mm} / \mathrm{s}$ to $1.2 \mathrm{~mm} / \mathrm{s}$ the mechanical properties of the FS welded aluminum alloy AA6351 increases and then decreases. At lowest welding speed $(0.5 \mathrm{~mm} / \mathrm{sec})$ and highest welding speed $(2.4$ $\mathrm{mm} / \mathrm{sec}$ ) lower tensile strength is observed. This is due to the increased frictional heat and insufficient frictional heat generated respectively [25]. Also higher welding speed produce poor plastic flow of the material it causes poor consolidation of the metal interface [14].

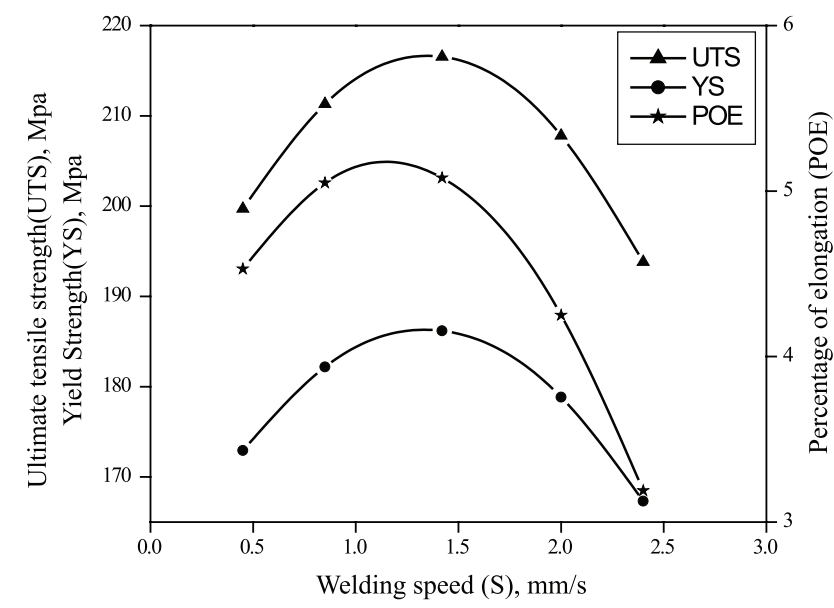

Figure 10. Direct effect of welding speed on mechanical properties

\subsection{Effect of axial force (F)}

Figure 11 depict the direct effect of axial force on mechanical properties. It is observed that the axial force increases from 1 tone to 1.5 tones the mechanical properties of the weld material increases and then decreases. This may be due to insufficient coalescence of transferred material. At highest axial force the plunge depth of the tool into the work pieces is higher which results in lower tensile strength [14].

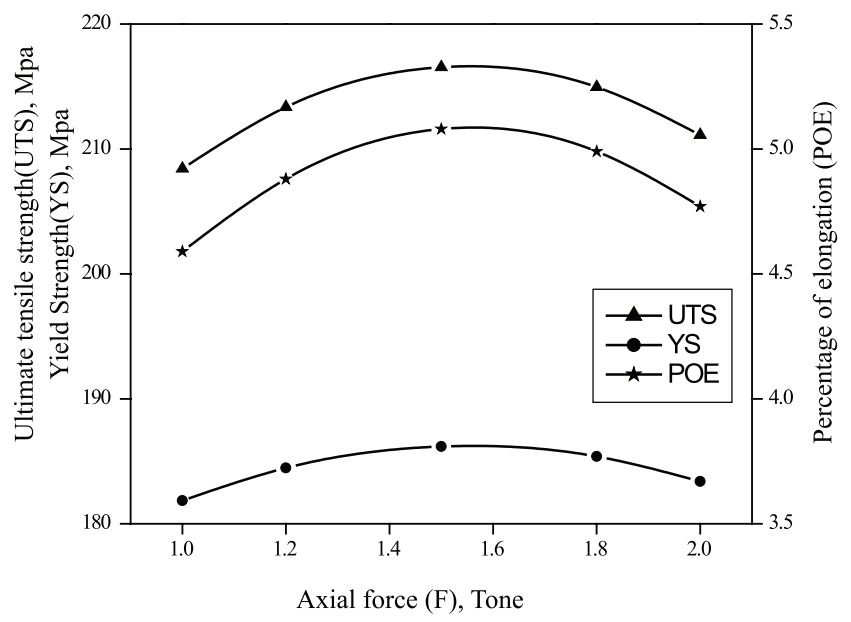

Figure 11. Direct effect of axial force on mechanical properties

\section{Conclusions}

The following conclusions are arrived at from the above investigations.

1. The relationships between process parameters for FS welding of AA6351 aluminum alloy have been established. The response surface methodology was adopted to develop the regression models, which were checked for their adequacy using ANOVA test, scatter diagrams and found to be satisfactory.

2. Confirmation experiments showed the developed models are reasonably accurate.

3. The increase in the tool rotational speed, welding speed and axial force leads to the increase in the ultimate tensile strength; and it reaches a maximum value and then decreases. This trend is common for yield strength and percentage of elongation.

\section{Acknowledgements}

The authors are grateful to the Management and Department of Mechanical Engineering, Coimbatore Institute of Technology, Coimbatore, India for extending the facilities of Welding Research Laboratory to carry out this investigation.

\section{References}

1. R. Nandan, T. DebRoy and H. K. D. H. Bhadeshia, "Recent advances in friction stir welding-process, weldment structure and properties", Progress in Materials Science, vol.53, 980-1023, (2008)

2. W. M. Thomas, E. D. Nicholas, J. C. Needham, M. G. Murch, P. TempleSmith and C. J. Dawes, "Friction stir butt welding", International Patent Application No. PCT/GB92/ 02203, December 1991.

3. C. J. Dawes and W. M. Thomas, "Friction stir process welds aluminum alloys", Welding Journal 75, 41-44, (1996).

4. Jae-Hyung Cho, E. Donald, Boyce and Paul R. Dawson, "Modeling strain hardening and texture evolution in friction stir welding of stainless steel", Material Science Engineering A, 398, 146-163. (2005).

5. I. Kalemba, S. Dymek, C. Hamilton and M. Blicharski, "Microstructural investigation of friction stir welded 7136-T76511 aluminium”, Proceedings of the $13^{\text {th }}$ International Conference on Electron Microscopy,'EM2008',
Zakopane, 79 , (2008).

6. H. Uzun, C.D. Donne, A. Argagnotto, T. Ghidini and C. Gambaro, "Friction stir welding of dissimilar Al 6013-T4 to X5CrNi18-10 stainless steel", Materials and Design, 26, 41- 46, (2005).

7. P. Cavaliere, R. Nobile, F. W. Panella and A. Squillance, "Mechanical and microstructural behavior of 2024-7075 aluminium alloy sheets joined by friction stir welding", International Journal of Machine Tools and Manufacture, 46, 588-594, (2006).

8. L. Litynska, R. Braun, G. Staniek, C. Dalle Donne and J. Dutkiewicz, "TEM study of the microstructure evolution in a friction stir-welded $\mathrm{Al}$ Cu Mg Ag alloy", Materials Chemistry and Physics, 81, 293-295, (2003).

9. C. Yeni, S. Sayer, O. Ertugrul and M. Pakdil, "Effect of post-weld aging on the mechanical stir and microstructural properties of friction welded aluminium alloy 7075", Archives of Materials Science and Engineering, 
34, 105-109, (2008).

10. C. Hamilton, S. Dymek and M. Blicharski, "Mechanical properties of al 6101-T6 welds by friction stir welding and metal inert gas welding", Archives of Metallurgy and Materials, 52, 67-72, (2007).

11. M. St. Weglowski, Y. Huang and Y. M. Zhang, "Effect of welding current on metal transfer in GMAW", Archives of Materials Science and Engineering, 33, 49-53, (2008).

12. D. T. Thao, J. W. Jeong, I. S. Kim and J. W. H. J. Kim, "Predicting LapJoint bead geometry in GMA welding process", Archives of Materials Science and Engineering, 32, 121-124, (2008).

13. H. D. Chandler and J. V. Bee, "Cyclic strain induced precipitation in a solution treated aluminum alloy", Acta Metallurgica, 35, 2503-2510, (1987).

14. K. Elangovan, V. Balasubramanian and S. Babu, "Predicting tensile strength of friction stir welded 6061 aluminium alloy joints by mathematical model”, Materialanddesign, 30, 188-193, (2009).

15. V. Gunaraj and N. Murugan, "Application of response surface methodology for prediction weld bead quality in submerged arc welding of pipes", Journal of Material Processing Technology, 88, 266-275, (1999).

16. K. Manonmani, N. Murugan, and G. Buvanasekaran, "Effect of process parameters on the weld bead geometry of laser beam welded stainless steel sheets", International Journal of Joining of Material, 17, 103-109, (2005).

17. M. Balasubramanian, V. Jayabalan and V. Balasubramanian, "Developing mathematical models to Predict tensile properties of pulsed current gas tungsten arc welded Ti-6Al-4V alloy", Materials and Design, 29, 92-97,
(2008).

18. P. K. Palani, and N. Murugan, "Optimization of weld bead geometry for stainless steel claddings deposited by FCAW", Journal of Materials Processing Technology, 190, 291-299, (2007).

19. S. J. Vijay and N. Murugan, "Influence of tool pin profile on the metallurgical and mechanical properties of friction stir welded Al-10 wt.\% TiB2 metal matrix composite", Materials and Design, 31, 3585-3589, (2010).

20. K. Elangovan and V. Balasubramanian, "Influences of tool pin profile and tool shoulder diameter on the formation of friction stir processing zone in AA6061 aluminum alloy", Material and Design, 29, 362-373, (2008).

21. W. G. Cochran and G. M. Cox, "Experimental Designs", $2^{\text {nd }}$ edition, New York, John Wiley \& Sons Inc., 350, 1957.

22. S. Ramasamy, D. Gould and Workman, "Design of experiments study to examine the effect of polarity on stud welding", Welding Journal, 81, 1926, (2002).

23. I. S. Kim, K. J. Son, Y. S. Yang and P. K. D. V. Yaragada, "Sensitivity analysis for process parameter parameters in GMA welding process using factorial design method, International Journal of machine tools and manufacture", 43, 763-776, (2003).

24. S. Lomolino, R. Tovo and J. Dos Santos, "On the fatigue behavior and design curves of friction stir butt welded Al alloys", International Journal of Fatigue, 27, 305-316, (2005).

25. J. Colligan, J. Paul, Konkol, J. James, Fisher and R. Pickens Joseph, "Friction stir welding demonstrated for combat vehicle construction", Welding Journal, 1-6, (2003). 